\title{
Kajian Karakteristik Spektrum Tandan Buah Segar (TBS) Kelapa SaWit Berdasarkan TINGKat Kematangan MENGgUNAKAN SPEKTROFOTOMETER UV - VIS
}

\author{
A Study of Spectrum Characteristics of Oil Palm Fresh Fruit Bunch (FFB) Based on Maturity Rate \\ by Using UV-Vis Spectrophotometer
}

\author{
Ahmad Thoriq'), Sam Herodian ${ }^{2)}$, Agus Sutejo ${ }^{2)}$ \\ 1) Departemen Teknik Pertanian dan Biosistem, FTIP - Univeristas Padjadjaran \\ ${ }^{2)}$ Departemen Teknik Mesin dan Biosistem, Fateta - IPB \\ email : thoriq.unpad@gmail.com
}

\begin{abstract}
ABSTRAK
TBS kelapa sawit memiliki spectrum warna yang dapat dibedakan berdasarkan tingkat kematangan. Saat ini proses pemanenan masih mengandalkan tenaga manusia menyebabkan kualitas panen bersifab subjektif. Penggunaan sensor diperlukan dalam menentukan standar kematangan TBS yang siap dipanen. Penentuan sensor yang tepat dalam membedakan kematangan di perlukan kajian karakteristik optic TBS. Penelitian ini bertujuan mempelajari karakteristik spektrum TBS berdasarkan tingkat kematangan. Metode yang digunakan pada penelitian ini adalah reflektansi gelombang cahaya tampak yang dipancarkan TBS menggunakan spektrofotometer UV-Vis. Citra TBS ditangkap oleh digital spotting scope dan reflektan TBS akan dibaca oleh spektrometer ocean optics USB 650 (fiber optic solids) pada panjang gelombang $200-850 \mathrm{~nm}$. Hasil penelitian menunjukkan tingkat kematangan untuk klon marihat, dampy dan selapan jaya dapat dibedakan pada kisaran panjang gelombang 630 $690 \mathrm{~nm}$. Pada panjang gelombang ini mengindikasikan terjadinya perbedaan warna antara buah yang belum matang dan buah matang. Setiap klon mempunyai karakteristik yang berbeda selama proses pematangan pada klon marihat kadar minyak optimal terjadi pada fraksi 2, sedangkan pada klon dumpy dan selapan jaya kadar minyak optimal terjadi pada fraksi 1 . Hubungan reflektan yang dipancarkan dari tiap fraksi dengan kadar minyak TBS untuk klon Marihat, Dumpy dan Selapan Jaya menghasilkan $\mathrm{R}^{2}$ secara berurutan masing - masing sebesar 0,$288 ; 0,614$ dan 0,516 .
\end{abstract}

Kata kunci : deteksi kematangan, tandan buah segar, reflektan, spektrofotometer UV-Vis

\section{ABSTRACT}

FFBs have a spectrum of colors that can be distinguished based on their level of maturity. Currently the harvesting process still relies on human power, and it causes the quality of the harvest is subjective. The use of sensors is required to determine the standard of maturity of FFBs that ready to harvest. Determining the right sensor to distinguish the characteristic of maturity requires optic FFBs assessment. The aim of this research was to study the characteristics of the spectrum FFBs based on the level of maturity. The method that used in this study was the reflectance of visible light waves emitted by FFBs using UV-Vis spectrophotometer. FFB digital image captured by a spotting scope and FFB reflectance will be read by the spectrometer optics ocean USB 650 (fiber optic solids) at a wavelength of 200-850 $\mathrm{nm}$. The results showed that the maturity levels of Marihat, Dampy and Selapan jaya clone was distinguished on the wavelength in the range of 630-690 $\mathrm{nm}$. These wavelength ranges would indicate immature and ripe fruit based on its colors. Each clone had the different characteristics during the maturation process. Optimal oil contents of Marihat clone occurred in second fraction, whereas optimal oil content of selapan jaya and dumpy clones occurred in first fraction. Unfavorable relationship between the data reflectance and FFB oil content with $R^{2}$ to clone Marihat, Dumpy and Selapan Jaya sequentially by 0.288; 0.614 and 0.516 .

Keywords: maturity detection, fresh fruit bunches, reflectance, UV - Vis spectrophotometer

Diterima : 25 Mei 2016 ; Disetujui : 18 Agustus 2016 ; Online Published : 31 Oktober 2016 


\section{PENDAHULUAN}

Penanganan panen TBS di lapang menjadi suatu kegiatan yang penting dalam upaya meningkatkan kualitas minyak sawit yang dihasilkan. Pemanenan buah kelapa sawit dilakukan pada saat kandungan minyak maksimal dan kandungan asam lemak bebas (ALB) minimal. Apabila pemanenan buah dilakukan pada keadaan lewat matang, maka minyak yang dihasilkan menggandung ALB dalam prosentase tinggi (lebih dari 5\%) sebaliknya, jika pemanenan dilakukan dalam keadaan buah belum matang, maka kadar ALB dan rendemen minyak yang dihasilkan rendah (Fauziet al. 2007). Secara umum penentuan kematangan buah sawit yang banyak dipakai adalah berdasarkan jumlah brondolan, yaitu tanaman dengan umur kurang dari 10 tahun jumlah brondolan kurang lebih 10 butir dan tanaman berumur lebih dari 10 tahun jumlah brondolan sekitar $15-20$ butir (Fauzi et al. 2007 ; Kiswanto et al.2008).

Menurut Muchtadi (1992) warna telah diduga menjadi panduan penting apakah kandungan minyak telah mencapai maksimum dimana buah siap dipanen.Sedangkan menurut Junkwon et al. (2009) pigmen minyak buah sawit seperti karotenoid dan klorofil mempengaruhi warna dari buah kelapa sawit, dimana buah mentah memiliki proporsi klorofil yang lebih tinggi yang secara bertahap menurun pada saat matang dan tidak terdapat pigmen klorofil pada buah matang.

Pemanenan yang masih mengandalkan tenaga manusia menyebabkan kualitas panen dipengaruhi pengalaman, keahlian, dan pengetahuan. Pengaruh faktor eksternal seperti : kelelahan, emosi, rasa bosan, faktor usia, kondisi mental, kesehatan dan cacat bawaan akan berdampak negatif pada hasil panen. Alternatif lain yang perlu dikembangkan adalah penggunaan sensor dalam mendeteksi tingkat kematangan TBS. Hal ini karena penggunaan sensor tidak dipengaruhi oleh faktor eksternal, dan sensor lebih baik dari manusia, namun memiliki keterbatasan. Beberapa sistem sensor untuk menentukan kematangan TBS kelapa sawit yang telah diteliti antara lain sensor optik camera base system (Abdullah et al. 2001, 2004 ; Makky
2005; Alfatni et al. 2008; Ismail et al. 2010; Razali et al. 2011; Hazir et al. 2011; May and Amaran 2011), kamera hiperspektruml (Junkwon et al. 2009), resonansi magnetik pencitraan dan resonansi magnetik nuklir (Shaarani et al. 2010), sensor kadar air (Yeow et al. 2010), sensor fluoresensi multiparametrik (Hazir et al. 2011, 2012), sensor optik aktif (Saeed et al. 2012), dan sensor ultrasonik (Suwannarat et al. 2012). Teknikteknik tersebut telah menggambarkan potensi menggunakan sensor optik dalam mendeteksi kematangan TBS. Namun, sebagian studi masih dilakukan dalam skala laboratorium, untuk itu pada penelitian ini akan dilakukan pengukuran tingkat kematangan TBS di dalam ruangan dan di luar ruangan dengan menggunakan spektrofotometer ultraviolet visible. Data hasil pengukuran berupa sifat pantulan dari spektrum TBS digunakan sebagai acuan dalam perancangan sistem deteksi kematangan TBS kelapa sawit.

Penelitian ini bertujuan untuk mempelajari karakteristik spektrum dengan metode reflektansi gelombang cahaya tampak TBS berdasarkan tingkat kematangan dan membangun hubungan antara kandungan kimia dengan spektra cahaya tampak TBS kelapa sawit.

\section{METODOLOGI PENELITIAN}

\section{Waktu dan Tempat}

Pengambilan data spektrum cahaya tampak dan analisa kandungan kimia TBS pada penelitian ini dilakukan di PT. Nirmala Agro Lestasi, Site Lamandau Propinsi Kalimantan Tengah. Sedangkan pengolahan data dilaksanakan di Laboratorium Ergonomika dan Elektronika, Departemen Teknik Mesin dan Biosistem, Fakultas Teknologi Pertanian, Institut Pertanian Bogor.

\section{Bahan dan Alat}

Bahan yang digunakan pada penelitian ini adalah tandan buah segar (TBS) kelapa sawit sebanyak 87 buah yang berasal dari klon Marihat, Dumpy dan Selapan Jaya.

Alat - alat yang digunakan pada penelitian ini antara lain : spektrometer ocean

2 Kajian Karakteristik Spektrum Tandan Buah Segar (TBS) Kelapa Sawit Berdasarkan Tingkat Kematangan Menggunakan Spektrofotometer UV - Vis 
optics USB 650,fiber optic solids, digital spotting scope (bushnell 15 - 45x, lcd 22x), laser pointer merah (660nm, $100 \mathrm{mw}$ ), lux meter, lampu halogen $(1000,600)$ watt, kain hitam, meteran, distance meter, peralatan laboratorium untuk analisa kimia TBS, komputer dan perlengkapannya.

\section{Prosedur Penelitian}

\section{Penelitian Pendahuluan}

Penelitian pendahuluan merupakan proses pembuktian bahwa digital spotting scope yang tehubung dengan probe fiber optik spektrofotometer Uv-Vis dapat digunakan dalam pengukuran reflektan TBS. Uji coba awal dilakukan dengan melakukan pengukuran reflektan dari beberapa kertas warna dengan jarak dan tingkat pencahayaan yang berbeda. Hasil pengukuran beberapa kertas warna dapat di lihat pada Gambar 1.

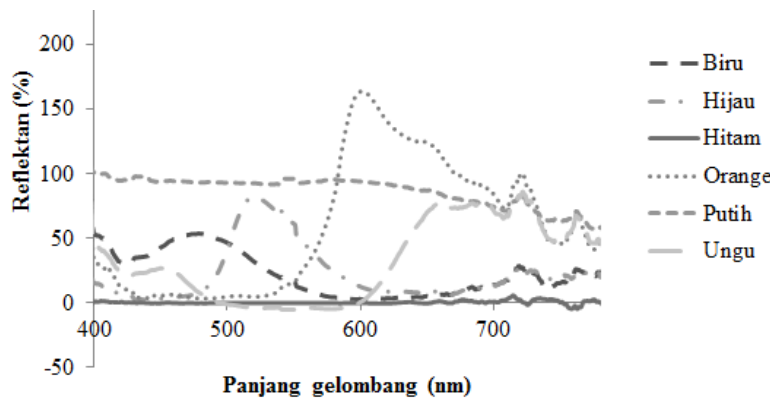

Gambar 1. Hasil pengukuran reflektan kertas warna menggunakan spektrofotometer UV Vis (sumber ; hasil penelitian pendahuluan)

Dari hasil pengukuran reflektan kertas warna tersebut, tampak terjadi perbedaan pola spektrum dari setiap warna yang diukur pada panjang gelombang visible (400 - 850) nm sehingga dapat disimpulkan bahwa teleskop dapat digunakan untuk pengukuran spektrum visible dari TBS. Hal ini karena terdapat perbedaan warna berdasarkan tingkat kematangan TBS. Penggunaan digital spotting scope pada pengukuran reflektan bertujuan sebagai media penangkap citra dari TBSdan pantulan dari citra tersebut dibaca oleh perangkat lunak ocean optics spektrumsuite.

\section{Persiapan Sampel TBS}

Penentuan sampel berdasarkan fraksi di lapangan dilakukan oleh mandor panen atau asisten afdeling yang telah berpengalaman lebih dari 5 tahun, secara umum penentuan fraksi yang dipanen dapat mengacu pada Tabel 1.Total sampel pada penelitian ini adalah sebanyak 87 buah TBS yang berasal dari klon Marihat, Dumpy dan Selapan Jaya. Setiap klon tersebut terdiri atas4 (empat) tingkat kematangan yaitu mentah (fraksi 0), kurang matang (fraksi 1) matang (fraksi 2 dan fraksi 3), lewat matang (fraksi 4).

Tabel 1. Beberapa tingkatan fraksi matang panen pada tanaman kelapa sawit

\begin{tabular}{ccc}
\hline Fraksi & \multicolumn{1}{c}{ Jumlah brondolan } & Tingkat kematangan \\
\hline 00 & tidak ada, buah berwarna hitam & sangat mentah \\
0 & $1-12,5 \%$ buah luar membrondol & mentah \\
1 & $12,5-25 \%$ buah luar membrondol & kurang matang \\
2 & $25-50 \%$ buah luar membrondol & matang 1 \\
3 & $50-75 \%$ buah luar membrondol & matang 2 \\
4 & $75-100 \%$ buah luar membrondol & lewat matang 1 \\
5 & buah dalam juga membrondol, ada & lewat matang 2 \\
\hline
\end{tabular}

\section{Pengambilan Spektrum UV -Vis TBS}

Pada penelitian ini reference putih yang digunakan adalah melamin dan reference hitam melamin yang dicat menggunakan cat pilok dull black. Citra TBS ditangkap oleh digital spotting scope dan reflektan TBS akan dibaca oleh spektrometer ocean optics USB 650 (fiber optic solids) pada panjang gelombang 200-850 nm. Untuk memastikan titik pengukuran TBS, maka digunakan laser sebagai penunjuk dan citra dari TBS dapat ditampilkan oleh display yang terdapat pada digitalspotting scope. Pembacaan spektrum akan dilakukan dengan menggunakan perangkat lunak ocean optics spektrumsuite yang terhubung dengan spectrometerUSB 650 - fiber optic solids(Gambar 2).

Jarak pengukuran akan mempengaruhi perbesaran dari digital spotting scope, diameter objek yang ditangkap oleh digital spotting scope diatur sebesar $20 \mathrm{~cm}$ sehingga perubahan jarak pengukuran akan berpengaruh pada perubahan perbesaran dari digital spotting scope. Pengaturan perbesaran berdasarkan jarak pengukuran dapat di lihat pada Tabel 2. 


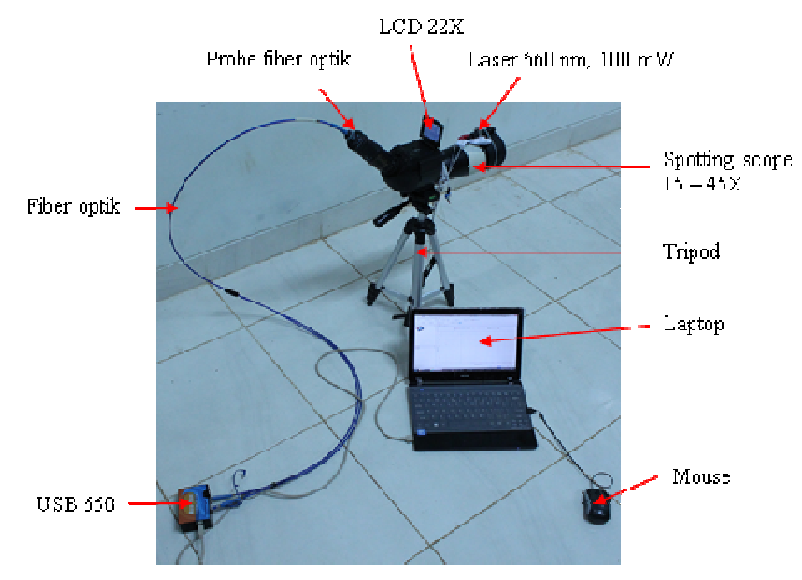

Gambar 2. Spotting scope,spectro-fotometer USB 650 dan perlengkapannya

Tabel 2. Pengaturan perbesaran berdasarkan jarak pengukuran

\begin{tabular}{cc}
\hline $\begin{array}{c}\text { Jarak pengukuran } \\
(\mathrm{m})\end{array}$ & $\begin{array}{c}\text { Perbesaran } \\
\text { digital spotting scope }\end{array}$ \\
\hline 2 & 12 \\
7 & 25 \\
10 & 40 \\
15 & 45 \\
\hline
\end{tabular}

Pengukuran reflektan dilakukan dalam ruangan tertutup, hal ini bertujuan untuk mengontrol factor eksternal yang dapat mempengaruhi hasil pengukuran bila proses pengukuran dilakukan di lapang. Sumber cahaya yang digunakan adalah lampu halogen 600 Watt, dan halogen 1000 Watt yang dipasang pada posisi membentuk sudut $45^{\circ}$ terhadap TBS yang diukur. Lampu halogen digunakan untuk mengantikan sinar matahari langsung yang juga memancarkan radiasi inframerah. Pengukuran dilakukan pada perlakuan jarak $2 \mathrm{~m}, 7 \mathrm{~m}, 10 \mathrm{~m}$ dan $15 \mathrm{~m}$ dan posisi TBS yang diukur adalah pada bagian yang tampak mata ketika TBS masih berada pada pohonnya. Pengukuran dilakukan sebayak tiga kali ulangan pada titik pengukuran yang berbeda dalam satu TBS yang sama. Metode pengukuran reflektan di dalam ruangan tampak atas seperti pada Gambar 3.

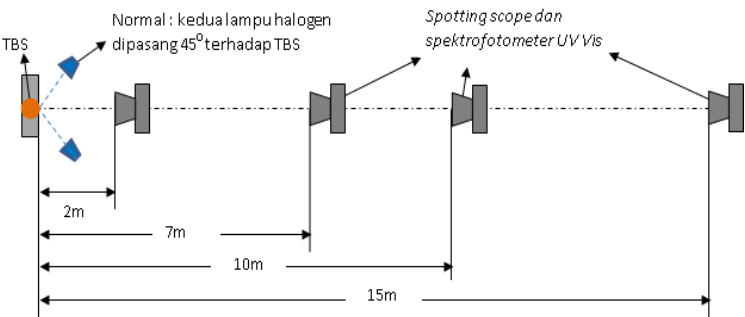

Gambar 3. Pengukuran reflektanTBS di dalam ruangan tampak atas

Langkah awal yang dilakukan pada pengukuran reflektan TBS adalah mencari integration time dengan mengukur reflektan reference putih dan reference hitam berdasarkan jarak pengukuran. Integration time merupakan waktu yang dibutuhkan sampai pada terbentuknya pola spektrum pada pengukuran TBS. Pada pengukuran reflektan TBS spektrofotometer UV - Vis diatur scans to averages : 10, boxcar width : 5 dan integration time berdasarkan Tabel 3.

Tabel 3. Integration time berdasarkan jarak pengukuran

\begin{tabular}{ccc} 
Pencahayaan & Halogen 600W & Halogen 1000W \\
\hline Jarak (meter) & $\begin{array}{c}\text { Integration } \\
\text { time } \\
\text { (miliseconds) }\end{array}$ & $\begin{array}{c}\text { Integration time } \\
\text { (miliseconds) }\end{array}$ \\
\hline 2 & 350 & 193 \\
7 & 910 & 490 \\
10 & 940 & 760 \\
15 & 2640 & 1444 \\
\hline
\end{tabular}

\section{Pengukuran ALB dan Kadar Minyak}

Pengambilan sampel untuk pengujian ALB dilakukan secara langsung setelah buah jatuh terpanen dengan mengambil 30 butir brondolan menggunakan kampak kecil dengan komposisi 10 butir bagian dalam, 10 butir bagian tengah dan 10 butir bagian luar. Sampel 30 butir tersebut dipilih dan dipastikan tidak terdapat luka, hal ini dilakukan untuk menghindari terjadinya peningkatan ALB yang disebabkan oleh enzim lipase kemudian sampel tersebut langsung dilakukan pengukusan selama 90 menit menggunakan rice cooker. 
Pengambilan sampel untuk analisa kadar minyak TBS dilakukan setelah pengukuran reflektan menggunakan spektrofotometer. Pada analisis ini mengikuti standar operasional prosedur (SOP) PT. Nirmala Agro Lestari yang telah sesuai dengan standar ditetapkan oleh Komite Akreditasi Nasional (LP-323-IDN). Pengukuran ALB dan kadar minyak dari setiap fraksi TBS dilakukan sebanyak 6 kali ulangan.

\section{Analisa dan Pengolahan Data}

Data hasil pengukuran reflektan TBS dianalisa untuk memperoleh panjang gelombang tertentu yang dapat membedakan kematangan TBS. Panjang gelombang yang dipilih tersebut akan dijadikan dasar pembuatan perangkat lunak sistem deteksi kematangan TBS berbasis sensor cahaya. Untuk mendapatkan korelasi hubungan antara reflektan dengan kadar minyak dan ALB berdasarkan tingkat kematangan dilakukan dengan menggunakan analisis regresi. Korelasi hubungan yang dipilih adalah yang memiliki $R^{2}$ terbaik pada rentang panjang gelombang yang dapat membedakan kematangan. $\quad R^{2}$ merupakan koefisien determinasi yang diartikan sebagai proporsi variasi tanggapan yang diterangkan oleh variable bebas $(x)$ dalam model.

\section{HASIL DAN PEMBAHASAN}

\section{Pola Spektrum Reflektan Cahaya Tampak Berdasarkan KIon Kelapa Sawit}

Pada penelitian ini pengukuran reflektan TBS dilakukan pada klon Marihat, Selapan Jaya dan Dampy. TBS dari setiap tingkat kematangan(fraksi) menghasilkan warna yang berbeda - beda dan warna tersebut direpresentasikan dalam bentuk pola sesuai dengan karakter warna dari tiap TBS. Menurut Novianty (2008) adanya perubahan warna

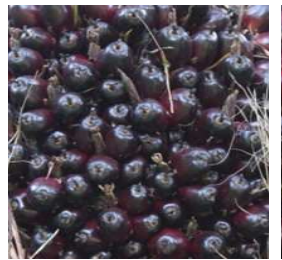

Fo

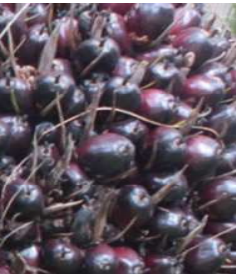

F0

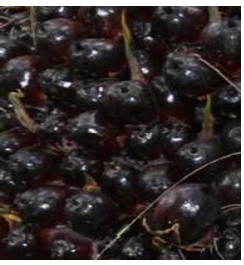

F0

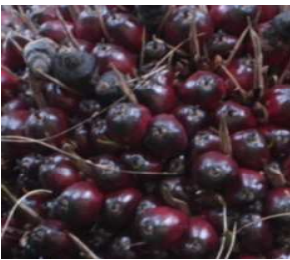

F1

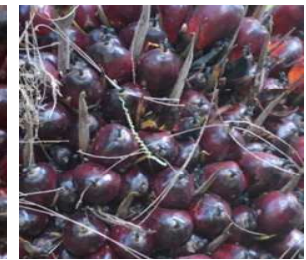

F2

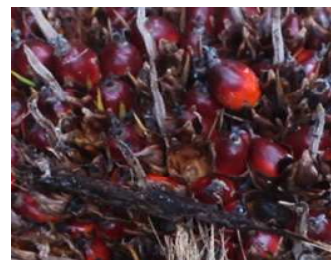

F3

(a) klon Marihat

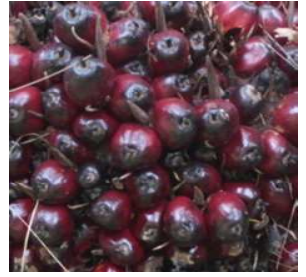

F1

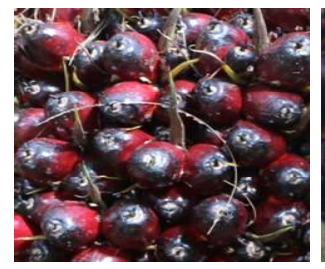

F1

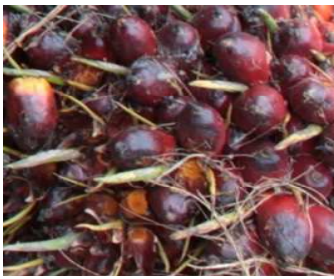

F2

(b) klon Dumpy

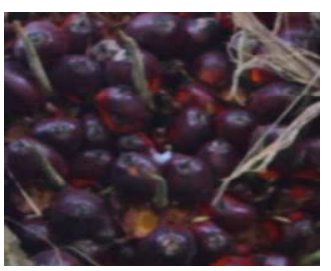

F2

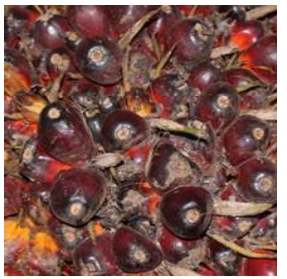

F3

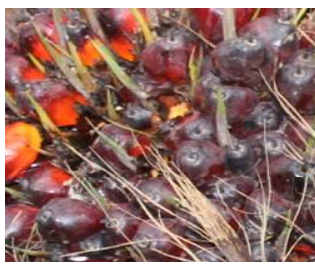

F3

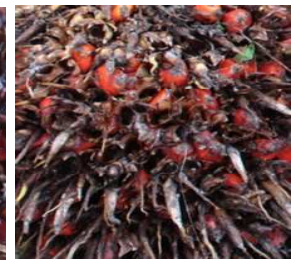

F4

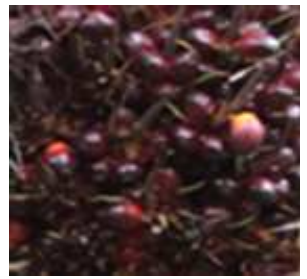

F4

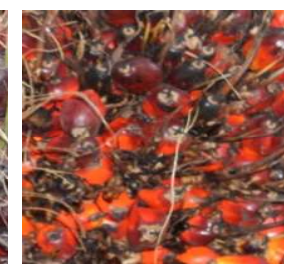

F4

(c) klon Selapan Jaya

Gambar 4. Warna TBS berdasarkan tingkat kematangan 
menyebabkan kemampuan penerusan dan pemantulan dari produk juga berubah. Variasi warna adalah bentuk variasi panjang gelombang radiasi elektromagnetik. Suatu bahan akan menyerap atau memantulkan sinar dengan berbagai panjang gelombang bergantung warnanya. Oleh karena itu, buah yang diberi perlakuan berupa pemberian sinarsinar pada daerah tertentu akan menentukan sifat fisik buah berupa warna dan tingkat kematangan buah berupa kadar air yang meningkat bila buah semakin masak. Pemberian sumber radiasi pada daerah cahaya tampak dapat menentukan pigmen yang terkandung oleh buah tersebut. Lebih lanjut menurut Saeed et al. (2012) perubahan warna buah sawit berdasarkan tingkat kematangan dapat diamati dengan memanfaatkan spektrum reflektan yang dipancarkan oleh buah. Secara umum warna dari setiap fraksi berdasarkan klon dapat di lihat pada Gambar 4.

Pengukuran reflektan TBS menggunakan spektrofotometer UV - Vis dan digital spotting scope dipengaruhi oleh jarak pengukuran, dan intensitas pencahayaan, namun pola spektra yang terbentuk akan tetap sama, yang membedakan adalah besarnya reflektan yang terukur. Untuk itu diperlukan standarisasi pengukuran (reference) berdasarkan jarak dan pencayaan yang digunakan. Pencahayaan yang digunakan pada penelitian ini adalah lampu halogen 1000 watt (17460 lux) dan lampu halogen 600 watt (10095 lux). Pengaruh pencahayaan terhadap hasil pengukuran dapat di lihat pada Gambar 5.

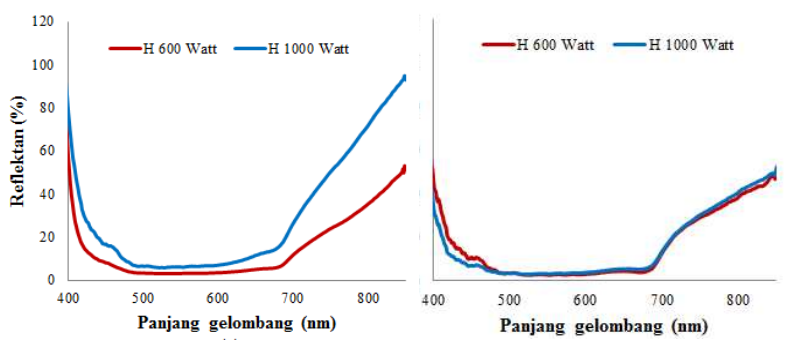

Gambar 5. Pola spektrum reflektan TBS (a) reference yang sama dengan pencahayaan yang berbeda, (b) reference yang sesuai dengan pencahayaan yang digunakan.
Berdasarkan pola spektra yang terbentuk, maka dengan menggunakan reference yang sama pada intensitas pencahayaan yang berbeda dapat disimpulkan bahwa semakin tinggi intensitas maka semakin tinggi reflektan yang terukur, oleh karena itu penggunaan reference harus disesuaikan dengan tingkat pencayaan yang digunakan. Seperti pada Gambar 5 (b) yang menunjukkan penggunaan reference sesuai dengan pencayaan yang digunakan.

Pola spektra yang terbentuk dan reflektan yang terukur cenderung identik antara pencahayaan lampu halogen 1000 watt dengan lampu halogen 600 watt, hal ini karena pengukuran telah terstandarisasi menggunakan reference disesuaikan berdasarkan sumber cahaya yang digunakan. Namun pada penggunaan reference yang sama pada jarak yang berbeda akan menghasilkan pola spektra relektan yang semakin kecil seiring bertambahnya jarak. Pola Spektrum Reflektan yang terbentuk dari tiap klon berdasarkan tingkat kematangan dapat di lihat pada Gambar 6.

Berdasarkan Gambar 6 terlihat bahwa setiap klon menghasilkan karakteristik yang berbeda - beda, pada klon marihat terdapat pola spektrum yang berhimpit pada F2 dan F3 dari klon Marihat, hal ini berarti kematangan tidak dapat dibedakan pada F2 dan F3 namun pada F0, F1, dan F4 kematangan dapat dibedakan pada rentang panjang gelombang $665-687 \mathrm{~nm}$. Pada klon Dumpy pola spektrum yang berhimpit terjadi pada F3 dan F4 dan kematangan dapat dibedakan untuk F0, F1 dan F2 pada rentang panjang gelombang $660-685 \mathrm{~nm}$. Sedangkan pada klon Selapan Jaya kematangan dapat dibedakan pada rentang panjang gelombang 630 $-688 \mathrm{~nm}$.

(Muchtadi, 1992). Sebagaimana terlihat pada Gambar 7 yang menunjukkan pola perubahan kadar minyak berdasarkan tingkat kematangan untuk klon Marihat, Selapan Jaya dan Dumpy. Tinggi rendahnya pola spektrum yang terbentuk dari tiap fraksi diduga karena dipengaruhi oleh intensitas cahaya pada saat pengukuran. Hal ini dikuatkan dengan melihat pola yang terbentuk pada tiap TBS dari tiga titik pengukuran dimana pada panjang gelombang $650-690 \mathrm{~nm}$ pola yang terbentuk tetap stabil sedangkan pada panjang gelombang $690-850$ berubah - ubah.

6 Kajian Karakteristik Spektrum Tandan Buah Segar (TBS) Kelapa Sawit Berdasarkan Tingkat Kematangan Menggunakan Spektrofotometer UV - Vis 

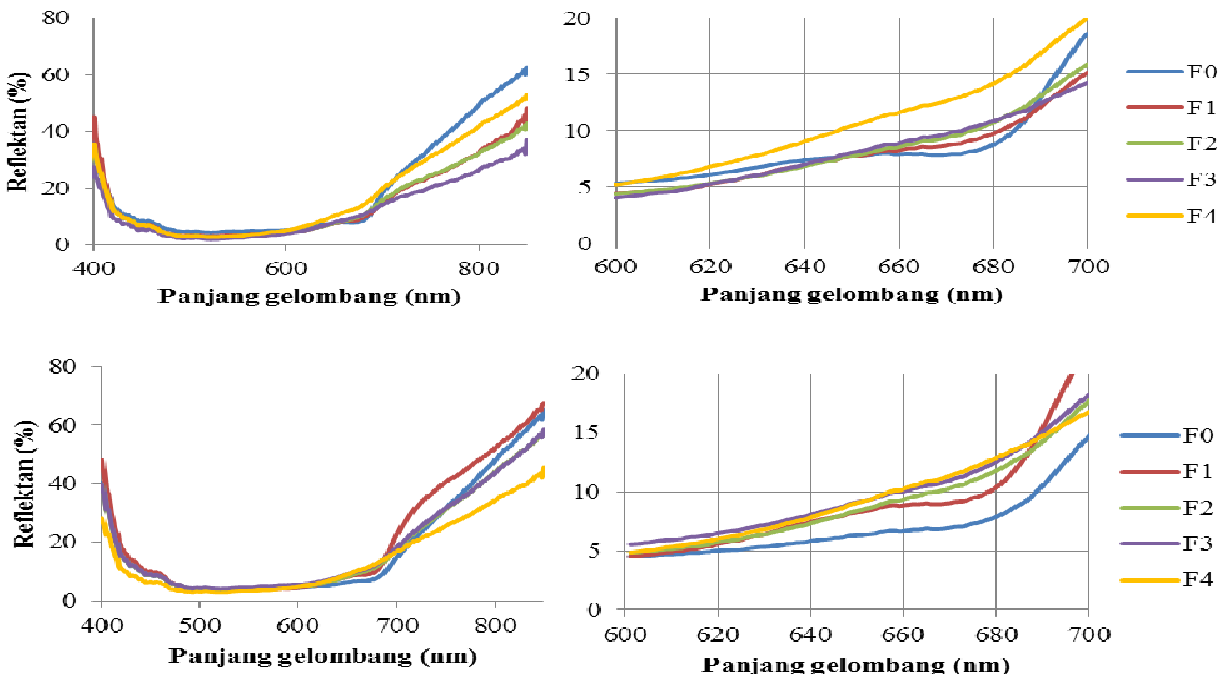

(b) klon Dumpy
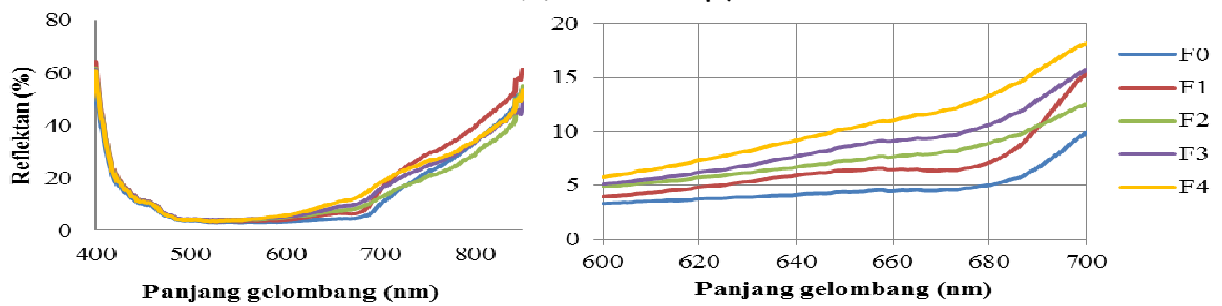

(c) klon Selapan Jaya

Gambar 6.Pola spekra setiap klon berdasarkan tingkat kematangan pada panjang gelombang $400-850 \mathrm{~nm}$ dan $600-700 \mathrm{~nm}$

\section{Klon Marihat}

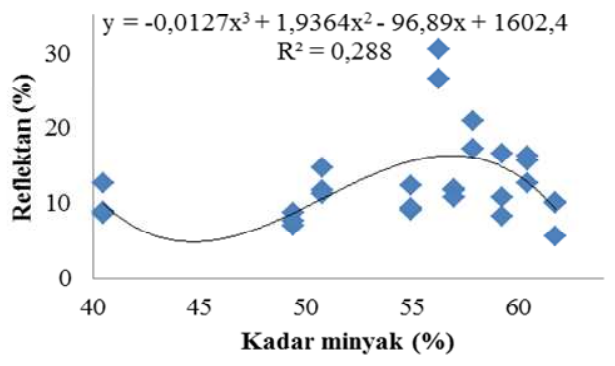

\section{Klon Dumpy}
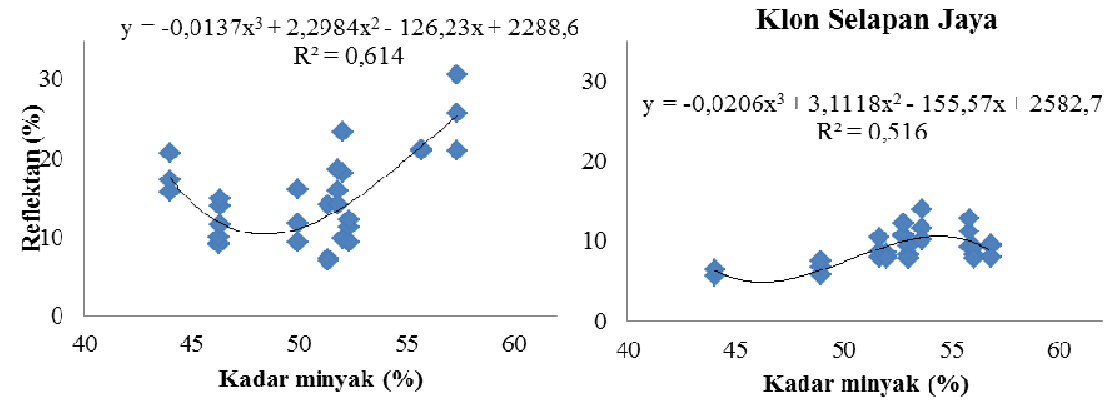

Gambar 7. Korelasi antara reflektansi dan kandungan minyak TBS; (a) klon Marihat pada panjang gelombang $673 \mathrm{~nm}$, (b) klon Dumpy pada panjang gelombang 685 $\mathrm{nm}$, (c) klon Selapan Jaya pada panjang gelombang $635 \mathrm{~nm}$ 


\section{Korelasi Reflektan Terhadap Kadar Minyak TBS}

Pada buah sawit yang masih muda (umur 3 minggu) sudah terdapat kadar minyak meskipun masih sedikit karena masih banyak mengandung air. Sedangkan pada buah yang dewasa (umur 10 minggu) dan tua (umur 13 sampai 16 minggu) ternyata diperoleh kadar minyak sawit yang makin meningkat, setelah itu terjadi penurunan terus sampai pada kondisi buah lewat matang yaitu umur 20 minggu

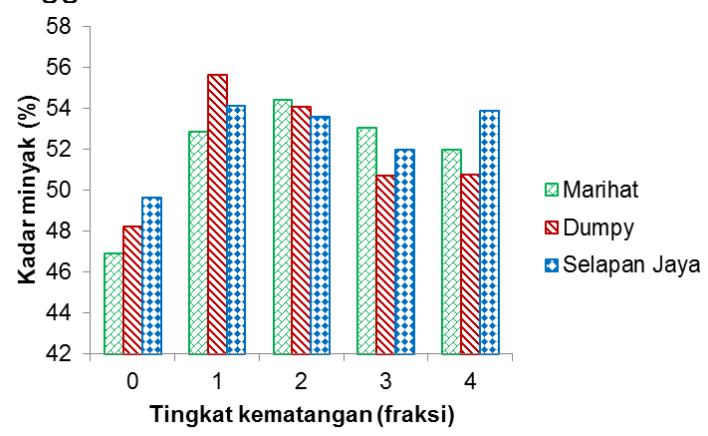

Gambar 8. Hubungankadar minyak minyak TBS setiap klon berdasarkan tingkat kematangan

Secara umum kadar minyak meningkat dari TBS mentah ke TBS matang kemudian menurun secara bertahap sampai pada kondisi TBS lewat matang. Hal ini karena pada buah sawit lewat matang dinding sel mesokarp dan inti sawit retak dan pecah, kantung lemak tersobek dan minyak keluar dari sel (Muchtadi 1992). Peningkatan kadar minyak dari setiap klon berbeda, pada klon Marihat kadar minyak optimal terjadi pada fraksi 2 , sedangkan pada klon Dumpy dan Selapan Jaya kadar minyak optimal terjadi pada fraksi 1. Hal ini karena terdapat perbedaan karakteristik dari setiap klon selama proses pematangan. Berdasarkan data reflektan pada pengukuran di dalam ruangan, panjang gelombang yang paling berpengaruh dalam memprediksi kadar minyak TBS pada rentang panjang gelombang 665 $687 \mathrm{~nm}$ untuk klon Marihat adalah $673 \mathrm{~nm}$ dengan nilai $R^{2}$ sebesar 0,407 , pada rentang panjang gelombang 660 - $685 \mathrm{~nm}$ untuk klon Dumpy adalah $685 \mathrm{~nm}$ dengan nilai $R^{2}$ sebesar 0,614 dan pada rentang panjang gelombang 630 - $688 \mathrm{~nm}$ untuk klon Selapan Jaya adalah $635 \mathrm{~nm}$ dengan nilai $R^{2}$ sebesar 0,516 Hubungan antara kadar minyak dan spektrum reflektan TBS pada pengukuran di dalam ruangan berdasarkan klon dapat di lihat pada Gambar 8.

Pada Gambar 8 tersebut terlihat bahwa hubungan kurang baik dalam memprediksi kadar minyak TBS dari setiap klon hal ini diduga dipengaruhi oleh pola spektrum pada rentang panjang gelombang $650-690 \mathrm{~nm}$ yang berhimpit antara fraksi 2 dan fraksi 3 untuk klon marihat dan pada F3 dan F4 untuk klon Dumpy seperti dapat di lihat pada Gambar 6 yang mengindikasikan kemiripan karakter warna dari sampel uji. Faktor lain yang mempengaruhi hubungan regresi antara reflektan dan kadar minyak TBS adalah besarnya nilai kadar minyak hasil analisa kimia. Pola yang terbentuk seperti pada Gambar 8 merupakan pendekatan dalam memprediksi kadar minyak secara tidak langsung, menggingat pada rentang panjang gelombang 650 - 690 ada indikasi terhadap penentuan tingkat kematangan TBS dan kadar minyak mempengaruhi proses kematangan TBS. Pendekatan secara langsung dapat dilakukan dengan menggunakan metode NIR untuk melihat struktur ikatan kimia pada buah sawit berdasarkan tingkat kematangan. Menurut Williams dan Norris (1990) kadar lemak yang terdiri atas ikatan $\mathrm{C}-\mathrm{H}$ menyerap pada panjang gelombang 1037 nm, 1620 $1765 \mathrm{~nm}$, dan $2310-2323 \mathrm{~nm}$.

\section{KESIMPULAN DAN SARAN}

\section{Kesimpulan}

Berdasarkan karakteristik pektrum TBS, Pada klon Selapan Jaya, semua tingkat kematangan dapat dibedakan pada panjang gelombang 630 - $688 \mathrm{~nm}$ namun pada klon Marihat, tingkat kematangan hanya dapat dibedakan pada F4 dengan panjang gelombang 665 - $687 \mathrm{~nm}$ dan pada klon Dampy, tingkat kematangan hanya dapat dibedakan pada F0 dengan panjang gelombang 660 - $685 \mathrm{~nm}$. Hubungan karakteristik reflektan dan kadar minyak TBS memiliki $R^{2}$ untuk klon Marihat, Dumpy dan Selapan Jaya secara berurutan masing -

8 Kajian Karakteristik Spektrum Tandan Buah Segar (TBS) Kelapa Sawit Berdasarkan Tingkat Kematangan Menggunakan Spektrofotometer UV - Vis 
masing hanya sebesar 0,288;0,614 dan 0,516. Sedangkan hubungan karakteristik reflektan dan asam lemak bebas TBS karena R2 untuk klon Marihat, Dumpy dan Selapan Jaya secara berurutan masing - masing hanya sebesar 0,$403 ; 0,686$ dan 0,438.

\section{Saran}

Perlu dilakukan penelitian lebih lanjut untuk mendeteksi kadar minyak TBS dengan menggunakan sensor pada rentang panjang gelombang Mid Infrared (NIR) yang dapat beresonansi dengan ikatan $\mathrm{CO}, \mathrm{CH}$ dan $\mathrm{NH}$.

\section{DAFTAR PUSTAKA}

Abdullah MZ, Guan LC, Azemi MBMN. 2001. Stepwise discriminant analysis for colour grading of oil palm using machine vision system. Trans IChemE 79 (3) : 223-231.

Abdullah MZ, Guan LC, Lim KC, Karim AA. 2004. The applications of computer vision system and tomographic radar imaging for assessing physical properties of food. J Food Eng. 61 (1) : 125-135.

Alfatni MSM, Shariff ARM, Shafri HZM, Saaed OMB, Eshanta OM. 2008. Oil palm fruit bunch grading system using red, green and blue digital numbers. J Appsci. 8 (8) : 1444-1452.

Fauzi Y, Widyastuti YE, Satyawibawa I, Hartono R.2007. Kelapa Sawit: Budidaya, Pemanfaatan Hasil dan Limbah, Analisis Usaha dan Pemasaran.Jakarta (ID) : Penebar Swadaya.

Hazir MHM, Shariff ARM, Amiruddin MD. 2012. Determination of oil palm fresh fruit bunch ripeness based on flavonoids and anthocyanin content. J Indcrops. 36 (1) : 466-475.

Hazir MHM, Shariff ARM, Amiruddin MD, Ramli AR, Saripan MI. 2012. Oil palm bunch ripeness classification using fluorescence technique. J Food Eng. 113 (1) : 534-540

Hazir MHM, Shariff ARM. 2011. Oil palm physical and optical characteristics from two different planting materials. J Appsci. 3 (9) : 953-962.

Ismail WIW, Razali MH. 2010. Outdoor colour recognition system for oil palm fresh fruit bunches (FFB). J Mach.Int. 2 (1) : 1-10.

Junkwon $\mathrm{P}$, Takigawa $\mathrm{T}$, Okamoto $\mathrm{H}$, Hasegawa $H$, Koike $M$, Sakai $K$, Siruntawineti J, Chaeychomsri W, Vanavichit A, Tittinuchanom $\mathrm{P}$ et al. 2009. Hyperspectral imaging for nondestructive determination of interval

Kiswanto, Purwanta JH, WijayantoB. 2008. Seri Buku Inovasi : Teknologi Budidaya Kelapa Sawit. Balai Besar Pengkajian dan Pengembangan Teknologi Pertanian. Jakarta (ID) : BPPP Deptan.

Makky M. 2005. Pengembangan algoritma pengolahan citra pada sistem netra mesin 3d (machine vision) untuk robot pemetik kelapa sawit[Tesis]. Bogor (ID) : Institut Pertanian Bogor.

May Z, Amaran MH. 2011. Automated oil palm fruit grading system usingartificial intelligence. IJVIPNS-IJENS. 11 (3) : 30 35

Muchtadi TR. 1992. Karakteristik komponen intrinsik utama buah sawit (Elaeis guineensis, Jacq.) dalam rangka optimalisasi proses kadar minyak minyak dan pemanfaatan provitamin $A$ [Disertasi]. Bogor (ID) : Institut Pertanian Bogor

Novianty I. 2008. Analisa spektroskopi reflektans vis-nir untuk mengetahui proses pematangan buah stroberi [Skripsi]. Bogor (ID) : Institut Pertanian Bogor.

Razali MH, Ismail WIW, Ramli AR, Sulaiman MN, Harun MHB. 2011. Technique on simulation for real time oil palm fruits maturity prediction. AJAR. 6(7): 18231830.

Saeed OMB, Sankaran S, Shariff ARM, Shafri HZM, Ehsani R, Alfatni MS, Hazir MHM. 2012. Classification of oil palm fresh fruit bunches based on their maturity using portable four-band sensor system. JCEA. 82 (1) 55-60. 
Shaarani SMD, Blanco AC, Amin MHG, Soon NG, Hall LD. 2010. Monitoring development and ripeness of oil palm fruit (Elaeis guneensis) by MRI and bulk NMR. IJAB. 12 (1) : 101-105

Suwannarat S, Khaorapapong T, Chongcheawchamnan M. 2012. Prediction of Oil Content in Fresh Palm Fruit based on an Ultrasonic Technique. J. Natsci 46 (1) : $318-324$.
William P, Norris K. 1990. Near Infrared Technology in The Agricultural and Food Industries. Ed ke-2. St.Paul, Minnesota, USA.

Yeow YK, Abbas Z, Khalid K. 2010. Application of microwave moisture sensor for determination of oil palm fruit ripeness. J Measci. 10 (1) : $7-14$. 